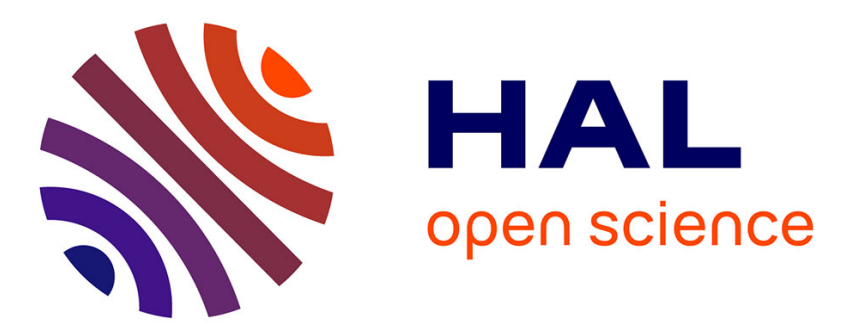

\title{
Analysis of thunderstorm and lightning activity associated with sprites observed during the EuroSprite campaigns: Two case studies
}

S. Soula, Van Der Velde O., J. Montanyà, T. Neubert, O. Chanrion, M. Ganot

\section{- To cite this version:}

S. Soula, Van Der Velde O., J. Montanyà, T. Neubert, O. Chanrion, et al.. Analysis of thunderstorm and lightning activity associated with sprites observed during the EuroSprite campaigns: Two case studies. Atmospheric Research, 2009, 91 (2-4), pp.514-528. 10.1016/j.atmosres.2008.06.017 . hal00441298

\author{
HAL Id: hal-00441298 \\ https://hal.science/hal-00441298
}

Submitted on 27 Jul 2021

HAL is a multi-disciplinary open access archive for the deposit and dissemination of scientific research documents, whether they are published or not. The documents may come from teaching and research institutions in France or abroad, or from public or private research centers.
L'archive ouverte pluridisciplinaire HAL, est destinée au dépôt et à la diffusion de documents scientifiques de niveau recherche, publiés ou non, émanant des établissements d'enseignement et de recherche français ou étrangers, des laboratoires publics ou privés. 


\title{
Analysis of thunderstorm and lightning activity associated with sprites observed during the EuroSprite campaigns: Two case studies
}

\author{
Serge Soula ${ }^{\text {a,b,* }}$, Oscar van der Velde ${ }^{\mathrm{a}, \mathrm{b}}$, Joan Montanyà ${ }^{\mathrm{c}}$, Torsten Neubert ${ }^{\mathrm{d}}$, \\ Olivier Chanrion ${ }^{\mathrm{d}}$, Michal Ganot ${ }^{\mathrm{e}}$ \\ a Université de Toulouse; UPS; LA (Laboratoire d' Aérologie); 14 avenue Edouard Belin, F-31400 Toulouse, France \\ b CNRS; LA (Laboratoire d' Aérologie); F-31400 Toulouse, France \\ Electrical Engineering Department, Technological University of Catalonia, Colon, 1, 08222, Terrassa, Spain \\ d National Space Institute, Technical University of Denmark, Juliane Maries Vej 30, 2100 Copenhagen O, Denmark \\ e Department of Geophysics and Planetary Sciences, Tel-Aviv University, Tel-Aviv 69978, Israel
}

\begin{abstract}
During the summers of 2003 to 2006 sprites were observed over thunderstorms in France by cameras on mountain tops in Southern France. The observations were part of a larger coordinated effort, the EuroSprite campaigns, with data collected simultaneously from other sources including the French radar network for precipitation structure, Meteosat with images of cloud top temperature and the Météorage network for detection of cloud-to-ground (CG) flash activity. In this paper two storms are analyzed, each producing 27 sprite events. Both storms were identified as Mesoscale Convective Systems (MCS) with a trailing stratiform configuration (ST) and reaching a maximum cloud area of $\sim 120,000 \mathrm{~km}^{2}$. Most of the sprites were produced while the stratiform area was clearly developed and during periods of substantial increase of rainfall in regions with radar reflectivity between 30 and $40 \mathrm{dBZ}$. The sprite-producing periods followed a maximum in the CG lightning activity and were characterized by a low CG flash rate with a high proportion of + CG flashes, typically around $50 \%$. All sprites were associated with +CGs except one which was observed after a -CG as detected by the Météorage network. This - CG was estimated to have $-800 \mathrm{C}$ km charge moment change. The peak current of spriteproducing $+\mathrm{CG}(\mathrm{SP}+\mathrm{CG})$ flashes was twice the average value of $+\mathrm{CGs}$ and close to $60 \mathrm{kA}$ with little variation between the periods of sprite activity. The SP+CG flashes were further characterized by short time intervals before a subsequent CG flash (median value $<0.5 \mathrm{~s}$ ) and with clusters of several CG flashes which suggest that SP+CG flashes often are part of multi-CG flash processes. One case of a lightning process associated with a sprite consisted of 7 CG flashes.
\end{abstract}

\section{Introduction}

Sprites are electric discharges in the Mesosphere above thunderstorms. They are so-called Transient Luminous Events (TLEs) which include the "blue jet" from thunderstorm cloud tops into the stratosphere and the "elve" at the base of the ionosphere. Sprites are the TLEs most commonly observed

* Corresponding author. Laboratoire d'Aérologie, OMP, 14 Avenue Edouard Belin, 31400 France. Tel.: +33 5613327 74; fax: +33 561332790 .

E-mail address: sous@sero.obs-mip.fr (S. Soula). from the ground, usually by TV-frame rate, light sensitive optical imagers. They come in a variety of forms that have given names such as "column", "carrot" or "angel" sprites. Sprites are thought to be positive streamers. They initiate around $70 \mathrm{~km}$ altitude, then propagate downward - at times with a branched structure - and occasionally continue with upward propagating elements and more diffuse luminosity (Pasko et al., 2002). After the first observation of sprites (Franz et al., 1990), it was soon realised that the large majority are induced by positive cloud-to-ground ( $+\mathrm{CG}$ ) flashes (Boccippio et al., 1995; Lyons, 1996). To date, only a few cases of sprites 
induced by - CG flashes have been reported (Barrington-Leigh et al., 1999) as discussed in Williams et al. (2007). It is also suggested that sprites are associated with "spider lightning", which is extended horizontal lightning in clouds that may feed several CG flashes (Mazur et al., 1998). Whereas the peak current in +CGs are not well correlated with sprite occurrences (Lyons et al., 2003) the charge moment change (CM) (defined as the product of the mean altitude of the charge reservoir in the cloud and the amount of charge lowered to ground by a CG flash) is a much better predictor, as first suggested by Wilson (1925). Recent work suggests that higher $\mathrm{CM}$ changes increase the probability of sprite generation (Huang et al., 1999; Hu et al., 2002) which becomes significant for CM changes above $600 \mathrm{C} \mathrm{km}$ (Cummer and Lyons, 2005).

As initially observed over the Great U.S. Plains (Lyons, 1994) and confirmed by later observations (Yair et al., 2004; Hayakawa et al., 2004; Pinto et al., 2004; Neubert et al., 2005) the storms which produce sprites are often mesoscale convective systems (MCSs). The Mesoscale Convective Complex (MCC) is the largest MCS with strong convective activity, horizontal dimensions from 150 to $1000 \mathrm{~km}$ and cloud top temperatures lower than $-32{ }^{\circ} \mathrm{C}$ (Maddox, 1980). The MCC is the most sprite-productive storm with several hundred sprites within 4-5 h (Lyons et al., 2003). However, sprites can also be produced by the non-MCSs observed in Europe (Neubert et al., 2001) or in Japan (Hayakawa et al., 2004). Thus, in most case studies reported in the literature, the production rate is one sprite every few minutes. It is then difficult to establish a threshold in the size or strength of a storm system needed for producing sprites.

A recent study by Lyons et al. (2006) describes the characteristics of storms producing sprites observed during the STEPS 2000 experiment conducted in the U.S.A. More than 2000 TLEs (mainly sprites) were observed from 3 dozen storms. The use of the Lightning Mapping Array (LMA) in the VHF range allowed identification of location and characteristics of lightning activity associated with the sprites. However, the analysis of sprite-producing storms has not been exhausted. During the EuroSprite campaigns, several smaller (relative to the U.S.) storms in France were identified as sprite producers, especially during the summers of 2003 with 101 sprite events observed (Neubert et al., 2005) and 2006 with 123 sprites observed from either of two sites. Among them, two MCS-type storms with 27 recorded sprite events each have been selected for analysis in this paper. First, the radar reflectivity distribution, the cloud top temperature and the structure, size and development of the storms are analyzed. Then, the cloud-to-ground (CG) lightning activity is discussed in relation to sprite production. The characteristics of the two storms are compared and several quantitative aspects are derived and compared with similar studies reported in the literature.

\section{Observation system and data}

Two camera systems at two different locations were fielded during the campaigns. One was located at the

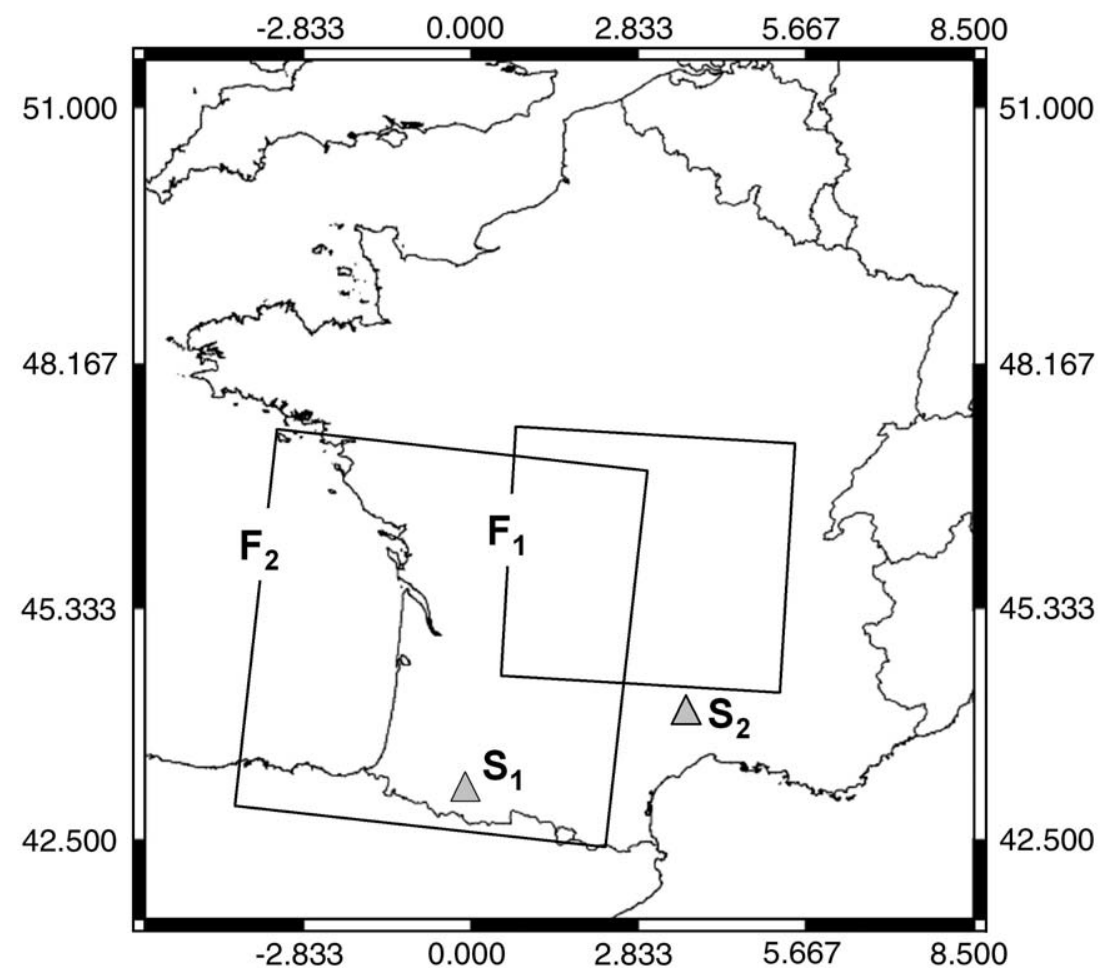

Fig. 1. Location of the French observation sites $S_{1}$ and $S_{2}$, at Pic du Midi and Mont Aigoual, respectively. Frames $F_{1}$ and $F_{2}$ display two domains used in the following figures to show the radar images of both storms which produced sprites, on 21 July, 2003, and on 11 September, 2006, respectively. $F_{1}$ and $F_{2}$ have dimensions of $300 \mathrm{~km} \times 300 \mathrm{~km}$ and $500 \mathrm{~km} \times 500 \mathrm{~km}$, respectively. 
Observatoire Midi Pyrenées at Pic du Midi at 2877 m altitude (Neubert et al., 2005). It includes two low-light, TV-frame rate CCD cameras mounted on a pan-tilt unit remotely controlled over the internet. The camera used here was equipped with a $16 \mathrm{~mm}, \mathrm{f} / 1.4$ lens with $22.5^{\circ}$ field-of-view (FOV). The video frames consist of two interlaced fields, with exposure time of $20 \mathrm{~ms}$ (PAL video system). The system time was synchronized to UT time through the Network Time Protocol (NTP) and correct to within $12 \mathrm{~ms}$. The events were detected and stored by automated trigger software in order to reduce the data volume. For the summer of 2006 two additional cameras were used at Mont Aigoual (44.121N $3.576 \mathrm{E}, 1565 \mathrm{~m})$. One camera was a Watec $902 \mathrm{H}$ with a $16 \mathrm{~mm}, \mathrm{f} / 1.4$ lens $\left(\mathrm{FOV}=23^{\circ}\right)$, mounted on a tripod, and connected to a laptop equipped with trigger software. The second camera, operated by Tel-Aviv University (TAU), was a Watec $100 \mathrm{~N}$ with a $12 \mathrm{~mm} \mathrm{f} / 0.8$ lens (FOV $=30.5^{\circ}$ ) also mounted on a tripod system and connected to a laptop with the same trigger software and a GPS and time-inserter unit. Fig. 1 shows the locations of the camera systems labelled $S_{1}$ and $S_{2}$, respectively. Also shown are two square-shaped frames $F_{1}$ and $F_{2}$ which bound the regions where the spriteproducing MCSs occurred and which will be used in the following figures for the description of the storms based on radar images. In order to accurately determine the direction of a sprite detected by a camera, we use freeware software which allows the superposition of the camera image of the sprite and the stellar background with the sky chart for any date and time from this observation site. The distance of the event, and therefore its location, cannot be determined directly from a single site as is the case for all our observed sprites. However, the sprites considered here can be assigned without any ambiguity to their causative CGs for which the locations are known from the Météorage lightning detection network.

For the description of the structure of the storms we use data from the meteorological radar network ARAMIS of 18 conventional radars (10 C-band and 8 S-band) covering France. Each radar has a range of approximately $250 \mathrm{~km}$ and produces images every $5 \mathrm{~min}$. The Plan Position Indicatortype images were made with a constant and low elevation of respectively $1.4^{\circ}$ (for low distance) and $0.4^{\circ}$ (for large distance) and therefore display the reflectivity factor at low altitude in the cloud systems. The cloud top temperature data are provided by the Meteosat satellites from EUMETSAT, placed in a geostationary orbit at $36,000 \mathrm{~km}$ altitude. This temperature is deduced from the 10.5 to $12.5 \mu \mathrm{m}$ thermal infrared band (IR) of the radiometer equipping each Meteosat satellite.

Data from a lightning detection network are used to obtain accurate positions and timing of CG lightning flashes. This French network run by Météorage adopts 17 sensors using both direction finding and time of arrival techniques to determine the location of positive and negative CG strokes over the entire country (Cummins et al., 1998). Its detection efficiency for CG flashes is $~ 90 \%$ and about $70 \%$ of the locations are determined with accuracy better than $4 \mathrm{~km}$. It provides the location, time, and peak current of each detected CG stroke. Strokes are considered associated with the same CG flash event provided they occur within $0.5 \mathrm{~s}$ and within $4 \mathrm{~km}$.

\section{Case studies}

\subsection{Case of 21 July 2003}

On 21 July 2003 a large region of low pressure located over North-Ireland with a trough over the Atlantic Ocean west of the Iberian Peninsula, organized a strong south-westerly flow over France. A convergence associated with warm air at low level and a cold anomaly in altitude created favourable conditions for storm development over Central France. The maximum value of CAPE on 20-21 July at 0000 UT was $1800 \mathrm{~J}$ $\mathrm{kg}^{-1}$ as found from a sounding made from the Nîmes station (43.86N; 4.40E). Fig. 2 shows the distribution of the radar reflectivity factor in the area $\mathrm{F}_{1}(300 \mathrm{~km} \times 300 \mathrm{~km})$ at $0100 \mathrm{UT}$, 0200 UT, and 0300 UT during the night of 20-21 July 2003. Convective cells started to develop before 0100 UT over southwestern France by forming a linear convective zone moving longitudinally north-eastwards with large reflectivity values (>60 dBZ) in several parts of the convective zone. The system entered $F_{1}$ before 0000 UT and at 0100 UT several cells with high reflectivity were visible. Between 0100 and 0200 UT the convective cells gathered to form a $50-\mathrm{km}$ line of high reflectivity reaching $65 \mathrm{dBZ}$. At the same time, a stratiform area developed to form a $250 \mathrm{~km} \times 125 \mathrm{~km}$ zone of relatively uniform reflectivity between 30 and $40 \mathrm{dBZ}$. This system exhibited the characteristics of a trailing stratiform MCS. Around 0300 UT the stratiform area remained relatively extended and several convective cells appeared along the right side of this zone. The red dotted lines in Fig. 2 show the FOV $\left(22.5^{\circ}\right)$ of the camera in $S_{1}$.

The cloud top temperature determined from Meteosat images gives an estimation of the cloud top altitude and the associated vertical convection inside the clouds. The coldest temperature indicates the highest altitude. Fig. 3 displays the area of cloud cover in different temperature ranges as a function of time between 0030 and 0430 UT. The maximum cloud top height (temperatures from $-65{ }^{\circ} \mathrm{C}$ to $-60{ }^{\circ} \mathrm{C}$ ) was observed at 0130 UT when most of the convective cells gathered together to form a line. While the surface with high values of the cloud top height increased until $0200 \mathrm{UT}$ to then decrease, the surface with intermediate values $\left(-55{ }^{\circ} \mathrm{C}\right.$ to $\left.-45{ }^{\circ} \mathrm{C}\right)$ increased appreciably from 0130 to 0300 UT. According to the soundings made in Nîmes at 0000 UT the temperature of $-55{ }^{\circ} \mathrm{C}$ was at $13 \mathrm{~km}$ altitude, which indicates a very strong vertical development of the convective cells. Between 0205 and 0313 UT 27 sprites were observed over this system. Fig. 4 shows 6 of the brighter ones as observed at a distance from $\mathrm{S}_{1}$ of around $450 \mathrm{~km}$. The period of sprite production lasted $1 \mathrm{~h}$ and $8 \mathrm{~min}$, which gave an average time interval between the sprites of $2 \mathrm{~min} 37 \mathrm{~s}$. The time interval between two successive sprites ranged from $9 \mathrm{~s}$ to $6 \min 25 \mathrm{~s}$, which means that this period of sprite production was relatively continuous and clearly identified in the lifetime of the MCS.

Fig. 5 displays the time series of the CG flash rates (+CG and -CG) and that of the sprite rate, calculated over 5-minute periods between 0000 and 0400 UT. The plot does not start at the beginning of the lightning activity, but at 0000 UT when the CG flash rates were high for the MCS located in the surrounding regions of $F_{1}$. The $-C G$ flash rate reached $25.2 \mathrm{~min}^{-1}$ at 0015 UT and then decreased until 0205 UT to below $5 \mathrm{~min}^{-1}$. It remained low for a 30-minute period (0205-0235 UT). It increased again after this period due to the development of new convective 

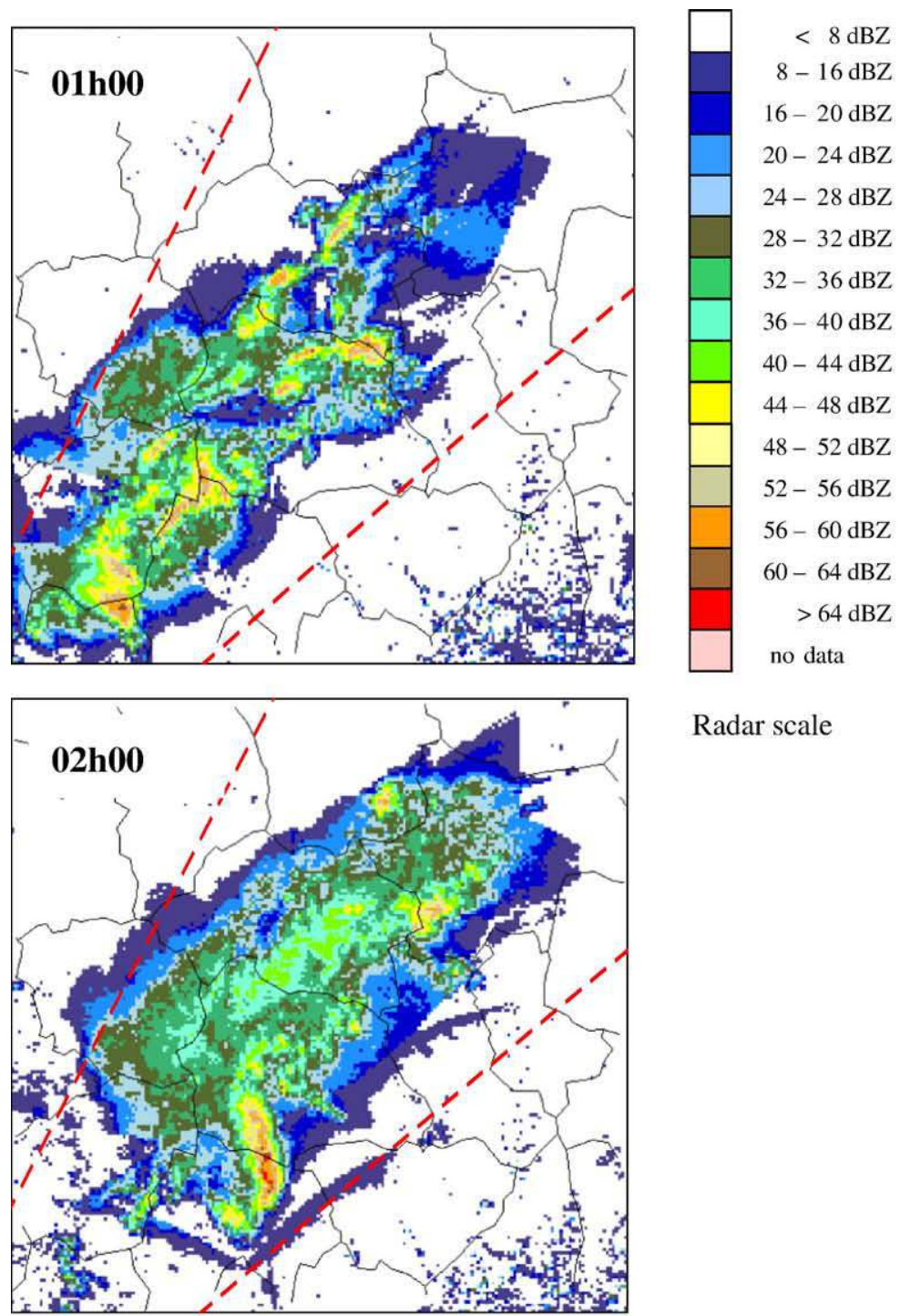

Radar scale

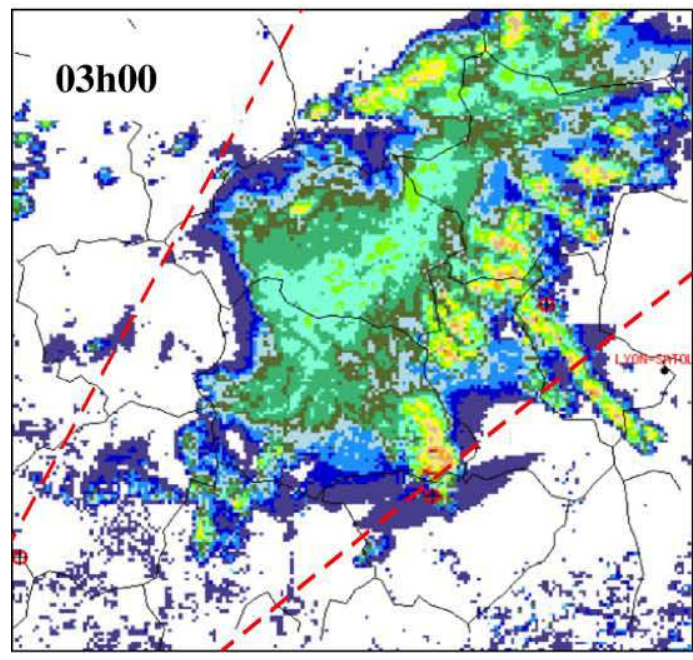

Fig. 2. PPIs (Plan Position Indicator) of the radar reflectivity factor in the MCS which produced 27 sprite events on 21 July, at 0100 UT, 0200 UT, and 0300 UT. The domain corresponds with the frame $F_{1}(300 \mathrm{~km} \times 300 \mathrm{~km})$. The red dotted lines indicate the FOV of the camera in $S_{1}\left(22.5^{\circ}\right)$. 


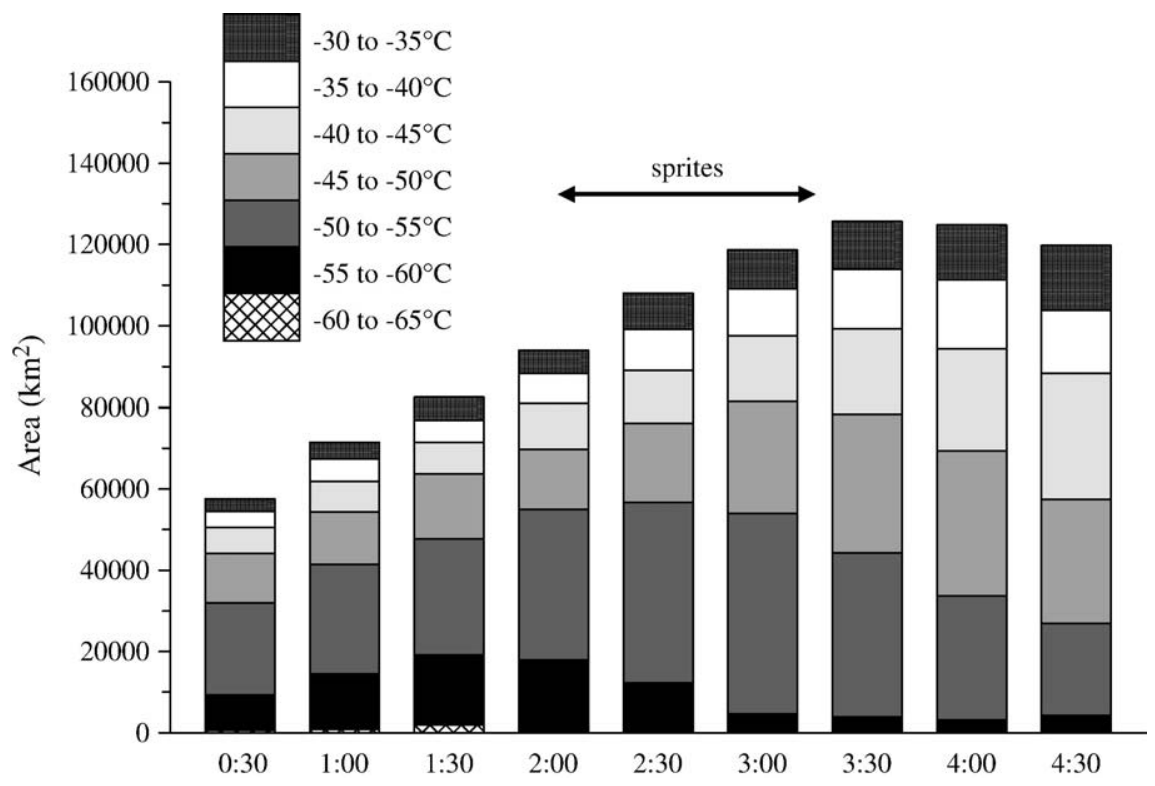

Fig. 3. Time series of the area of the cloud canopy at different atmospheric temperature intervals for the cloud top temperature: case of the MCS on 21 July.

cells, to a maximum of $13.4 \mathrm{~min}^{-1}$ reached at $0340 \mathrm{UT}$. In contrast, the +CG flash rate remained rather constant between 0.4 and $3.6 \mathrm{~min}^{-1}$. The proportion of +CG flashes was then larger than 30\% during the 30-minute period 0205-0235 UT, with a maximum value of $63 \%$ at 0215 UT. The sprite-producing period is well defined and corresponds to the period of low -CG flash rate and consequently, to the period of a high $+\mathrm{CG}$ rate. The maximum sprite rate was 3 in the considered 5-minute intervals, with only one interval without any sprite. After the last sprite was observed at 0313 UT, daylight started to appear and prevented sustained observation. However, chirps in infrasound identified as sprite signatures were observed until 05 UT presumably from the same active region (Farges et al., 2005). The distribution in time of the events shows that there is a preferential period in the lifetime of the storm for sprite production.

\subsection{Case of September 11th, 2006}

On 11th of September, a pronounced and elongated trough of low pressure was present over the nearby Atlantic Ocean north of Spain. The CAPE deduced from the sounding in Bordeaux at noon was $800 \mathrm{~J} \mathrm{~kg}^{-1}$. Such CAPE values and instability in the atmosphere remained all the day over France. The flow pattern over France was approximately southerly, advecting warm air into the area near the surface. Several thunderstorms producing strong rainfall developed in the evening, especially close to the Atlantic Ocean. Finally,
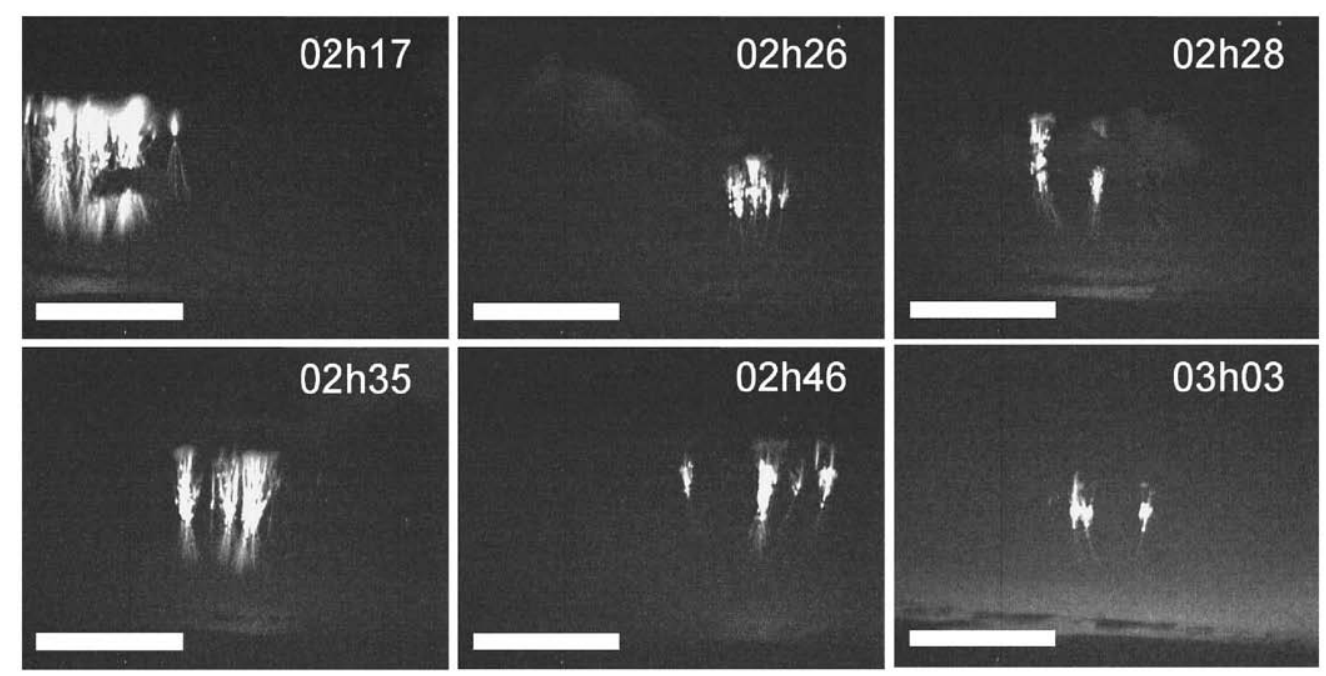

Fig. 4. Images of sprites observed from $\mathrm{S}_{1}$ over the MCS on 21 July $\left(\mathrm{FOV}=22.5^{\circ}\right)$. 


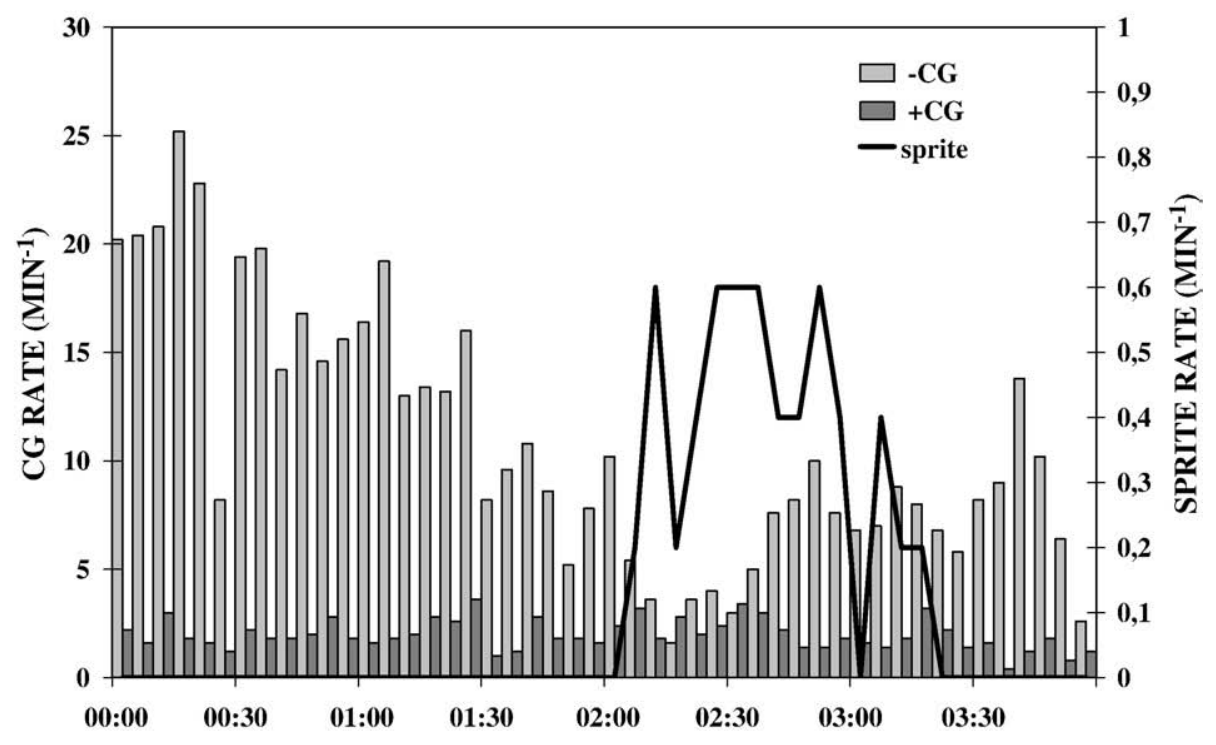

Fig. 5. Time series of the rates (5-minute averaged) for +CG and - CG lightning flashes, and sprites, produced by the MCS on 21 July.

a very large part of the country was affected by thunderstorms during that day and cumulative local precipitation attained values close to $100 \mathrm{~mm}$ in many areas. Fig. 6 displays the evolution of the radar reflectivity field in the $500 \mathrm{~km} \times 500 \mathrm{~km}$ area $\mathrm{F}_{2}$ in southwestern France, crossed by a convective system during the night of 11-12 September, for the period 1930 UT to 0115 UT. The beginning of the period is the time when the system first began generating sprites, as observed by the cameras, and the end of the period was marked by the last recorded sprite event. The system was a TS-type MCS moving northwards with a velocity of about $30 \mathrm{~km} \mathrm{~h}^{-1}$ with a convective line or cluster at its northern side. The size reached roughly $200 \mathrm{~km} \times 150 \mathrm{~km}$ at the time of maximum development at about 2030 UT. The system exhibited first a stratiform zone extending transversely to the northward direction of movement (1930-2200 UT) then the stratiform zone developed longitudinally during the later part (0000-0115 UT). The radar reflectivity values did not exceed $60 \mathrm{dBZ}$ between 1930 and $0115 \mathrm{UT}$ and the largest ones were observed in the first period, with several convective cells imbedded in the system. By considering the evolution of the system, it follows that the convective area slightly decreased during the first period (1930-2200 UT), then was reinforced between 2200 and 2300 UT and finally decreased after 2315 UT. On the other hand, the stratiform area substantially decreased after 2200 UT to be strongly reduced at 2300 UT and then developed again until 0115 UT when the convective area disappeared totally.

Fig. 7 shows the variation with time of the area of cloud top temperatures between 1800 UT and 0200 UT. According to the sounding made on 11 September in Saragossa (Spain), south of the area $\mathrm{F}_{2}$, the temperature $-60{ }^{\circ} \mathrm{C}$ was found at about $12 \mathrm{~km}$. The area of cloud top temperatures below $-60{ }^{\circ} \mathrm{C}$ (altitudes above $12 \mathrm{~km}$ ) was large and continued to increase until 1900 UT where it reached $\sim 33 \%$ of the area of the whole system $\left(\sim 10,000 \mathrm{~km}^{2}\right)$. After $1930 \mathrm{UT}$, the area of this convective region substantially decreased while that of the whole system continuously increased until 2130 UT, essen- tially for the benefit of the intermediate temperature values, between $-60{ }^{\circ} \mathrm{C}$ and $-40{ }^{\circ} \mathrm{C}$.

During that night 27 sprites were observed between 2018 and 0111 UT, from station $S_{2}$ indicated in the map of Fig. 1. The sprites appeared in three distinct periods of relatively continuous production, 2018-2149 UT, 2317-2337 UT, and 0009-0111 UT, with 12,5 and 10 events, respectively. The average time interval between two consecutive sprites was $8 \mathrm{~min} 12 \mathrm{~s}, 5 \mathrm{~min}$ and $6 \mathrm{~min} 46 \mathrm{~s}$ for the three periods, respectively. These average values were relatively close and higher than in the first storm. The maximum and minimum values of this interval were observed in the first period, $19 \min 17 \mathrm{~s}$ and $2 \min 28 \mathrm{~s}$, respectively. The last two periods were close in time and can be considered as one with a 32minute gap of production, for the analysis in the following section. The sprites were observed with one or both cameras located at $S_{2}$ and at a distance around $350 \mathrm{~km}$. Fig. 8 displays 6 of these sprites exhibiting a large diversity of shape, size and structure. Contrary to the first case, the sprites produced by this storm could be very different from one to the other. Some events were extensive, with a width of about $30 \mathrm{~km}$, for example the event detected at 2110 UT.

By considering the evolution of the storm structure in terms of convective and stratiform areas and the location of CG flashes, it is possible to distinguish two areas of lightning activity for this system. Fig. 9 shows the location of all +CG flashes generating sprites (SP+CG flashes) with different symbols for the three periods. They were well separated spatially, from south to north corresponding to the displacement of the system allowing separate analysis of the regions or periods. The CG flashes are therefore spatially divided into two groups, and Fig. 10 displays the rates of CG flashes and sprites for each group. The upper panel shows the lightning activity of the system when it was in the south of the region displayed in Fig. 6. The -CG flash rate reached the largest values around 1945 UT, up to $14.6 \mathrm{~min}^{-1}$, and then abruptly decreased after 2000 UT to a few $\mathrm{min}^{-1}$. The first period of sprites corresponds with the low -CG flash rates. The +CG 
flash rate did not undergo any similar strong decrease since it remained close to $2 \mathrm{~min}^{-1}$ and therefore the relative $+\mathrm{CG}$ rate was high reaching $50 \%$, when the first sprites were produced. The lower graph corresponds with the second phase of the MCS when it was within the northern parts of region $F_{2}$. The sprite production started when the -CG flash rate substantially decreased and was about $5 \mathrm{~min}^{-1}$, which was similar to the first period. Most sprites were produced when the -CG flash rate was low and the +CG proportion was high.

\section{Analysis and discussion}

\subsection{Cloud structure, precipitation activity and sprite production}

The two cases of MCS have almost the same size as estimated from infrared cloud top temperatures $\left(1.25 \times 10^{5} \mathrm{~km}^{2}\right.$ and $1.3 \times 10^{5} \mathrm{~km}^{2}$ ) and the same number of observed sprites (27).
For both systems the maximum area was reached during the sprite production period. These characteristics compare well with those of moderate MCS reported over the U.S. with areas of $1.2 \times 10^{5} \mathrm{~km}^{2}$ producing 15 sprites (Lyons et al., 2003) and $0.3 \times 10^{5} \mathrm{~km}^{2}$ (radar reflectivity area) producing 36 sprites (Lyons, 1996). Another study reported a long lifetime MCC over Kansas reaching $2.3 \times 10^{5} \mathrm{~km}^{2}$ with more than 50 sprites observed (São Sabbas and Sentman, 2003).

However, the number of sprites observed in our two cases is low compared to the numbers generally observed in the U.S. (Lyons et al., 2000, 2006). This is consistent with the size of the systems being just above the threshold of onset at $1 \times 10^{5} \mathrm{~km}^{2}$ estimated by Lyons et al. (2003) for MCCs that may eventually produce several hundreds of sprites. Another criteria suggested for sprite production is that the area of radar reflectivity must be above $20,000 \mathrm{~km}^{2}$ (Lyons, 1996), which was also exceeded.
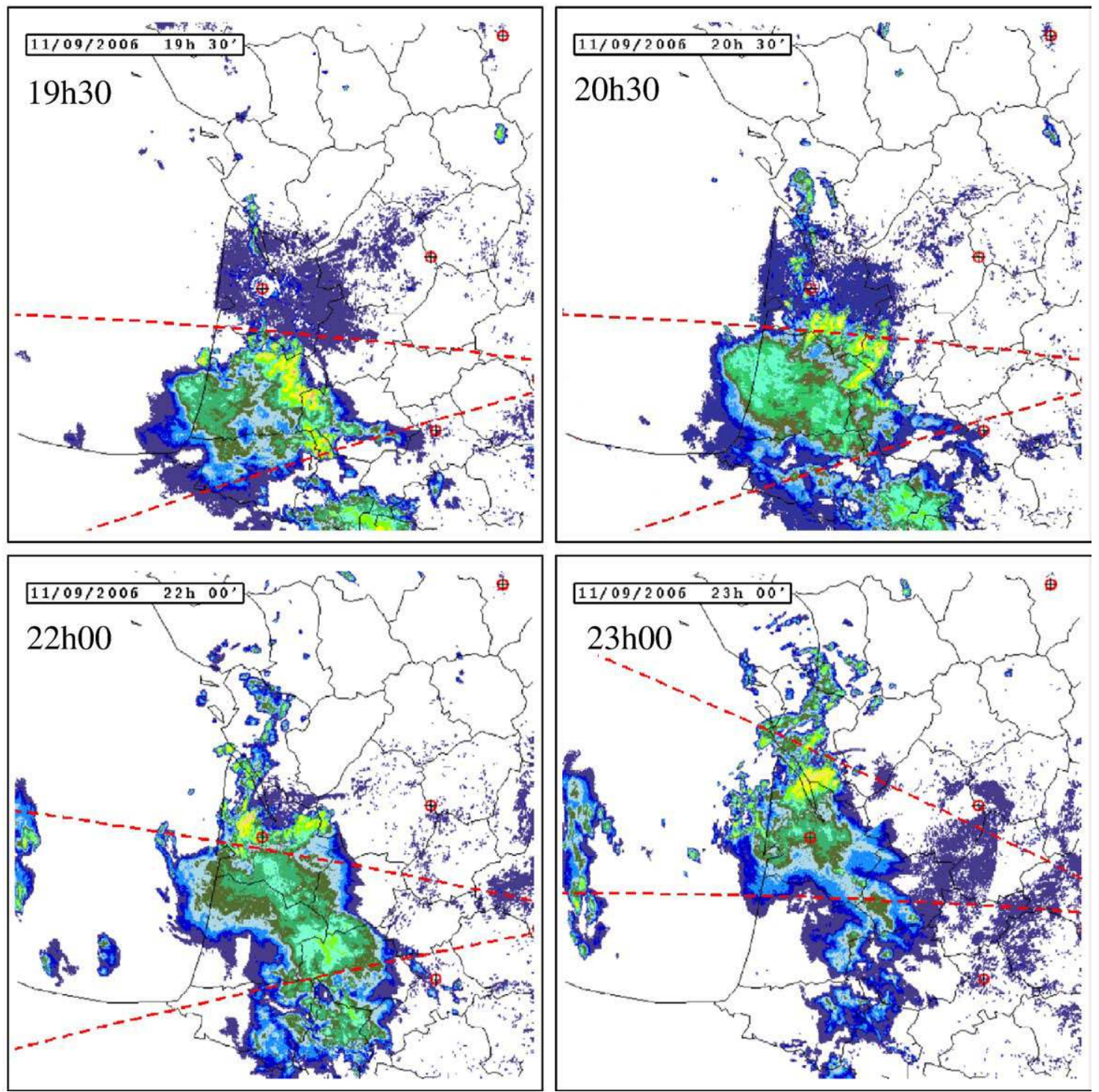

Fig. 6. PPIs (Plan Position Indicator) of the radar reflectivity factor in the MCS which produced 27 sprite events on 11 September, at 1930 UT, 2030 UT, 2200 UT, 2300 UT, 2315 UT, 0000 UT, and 0115 UT. The domain corresponds with F2 (500 km×500 km) and the radar scale is that of Fig. 2. 

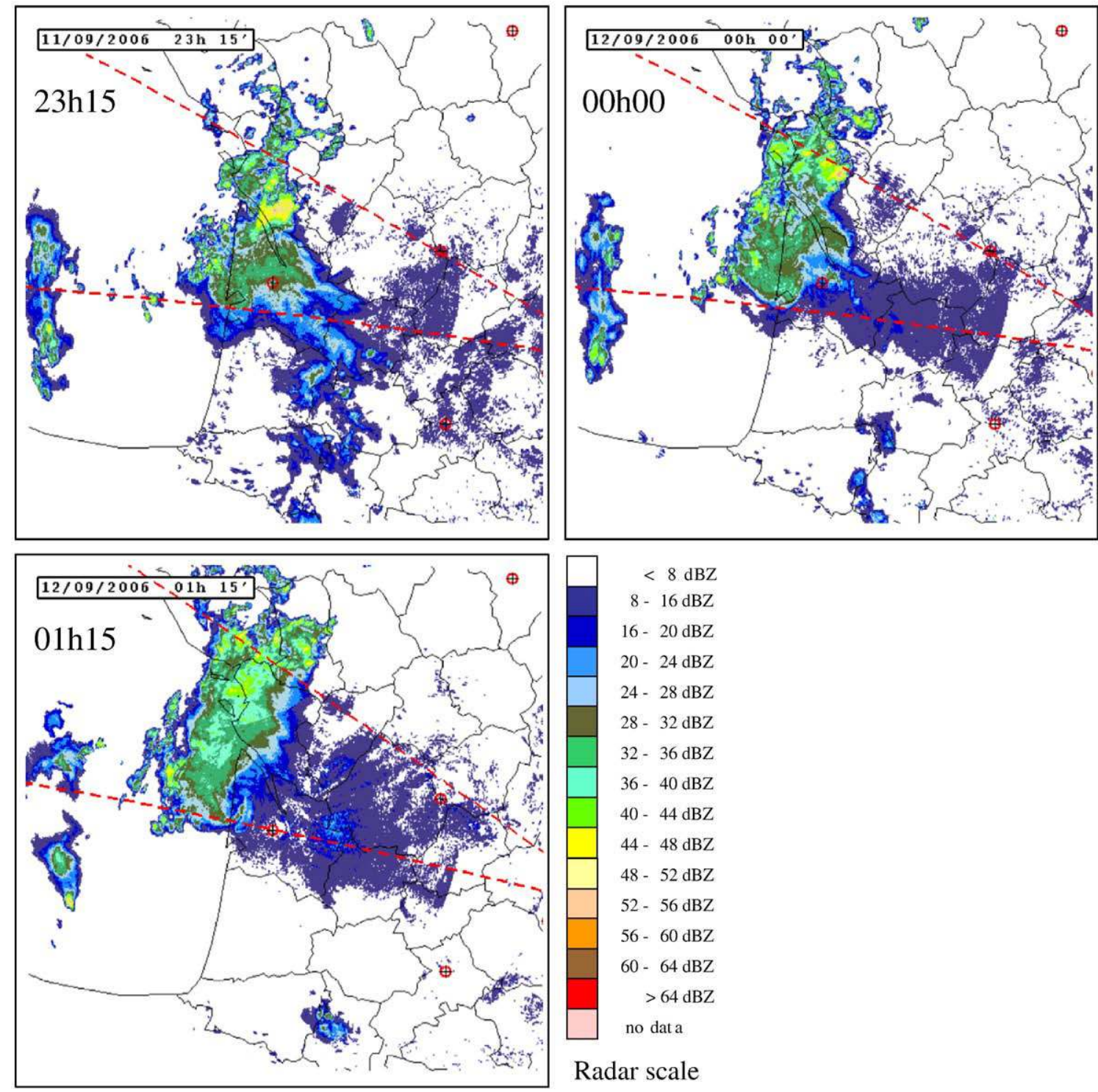

Fig. 6 (continued).

During both storms we found distinct periods of sprite production which clearly indicates that some special conditions are required. This conclusion is consistent with those based on storms elsewhere (e.g. São Sabbas and Sentman, 2003). For the second storm several periods of production could be identified which could be related to the two cycles of evolution of the storm seen for instance in the size of the system. In our cases sprite production started about $30 \mathrm{~min}$ and $1 \mathrm{~h}$ after the maximum area of coldest temperatures was reached. This is different from the case studied by São Sabbas and Sentman (2003) where the maximums in sprite production and cloud cover area of coldest top temperature were reached simultaneously. We suggest that the storm over Kansas was more severe (minimum temperature was below $-70^{\circ}$ ), larger and with a longer lifetime and that the onset for sprite production was reached before the end of the development of the storm. In our cases sprite production is better correlated with the cloud area with top temperature between $-55^{\circ} \mathrm{C}$ and $-50{ }^{\circ} \mathrm{C}$. This is consistent with the study of Lyons (1996) of a modest-size MCS where the majority of sprites were observed above the stratiform area of the MCS.

Based on the radar observations we made a quantitative analysis of the rainfall activity during the lifetime of the storms to search for signatures associated with the phase of the storm where sprites are generated. For this purpose the reflectivity factor was converted into a rainfall rate. Radar reflectivity $Z$, typically expressed in $\mathrm{dBZ}$, is related to a factor $Z_{0}$ expressed in $\mathrm{mm}^{6} \mathrm{~m}^{-3}$ by: $Z=10 \log Z_{0}$, where $Z_{0}$ is proportional to the density of particles $n$ and their diameter $D$ in the scanned radar beam volume $\left(Z_{0} \propto n D^{6}\right)$. For non-critical use as in this study, reflectivity $Z_{0}$ can be converted to the rainfall rate $R$ by the commonly used empirical relationship for the drop size distribution: $Z_{0}=200 R^{1.6}\left(Z_{0}\right.$ in $\mathrm{mm}^{6} \mathrm{~m}^{-3}$ and $R$ in $\mathrm{mm} \mathrm{h}^{-1}$ ) (Marshall-Palmer, 1948). Fig. 11 shows the 


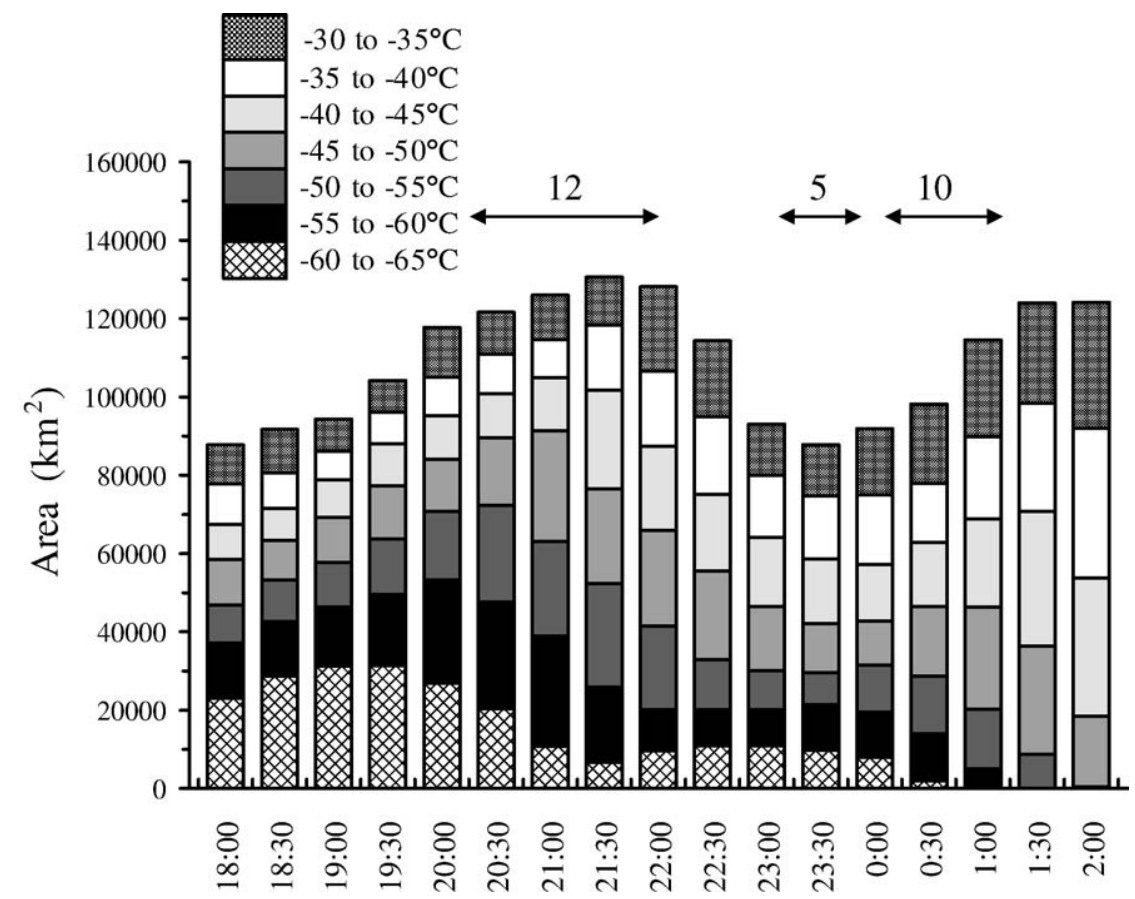

Fig. 7. Time series of the area of the cloud canopy at different atmospheric temperature intervals for the cloud top temperature: case of the MCS on 11 September. The arrows indicate the periods of sprite production with the number of sprites.

precipitation mass as a function of time for different intervals of radar reflectivity in the two storms. The best correlation between sprite production periods and precipitation is with the precipitation mass produced by the $35-40 \mathrm{dBZ}$ and $30-$ $35 \mathrm{dBZ}$ intervals. The value of the mass is around $1 \times 10^{7} \mathrm{~kg} \mathrm{~s}^{-1}$ for the first storm at the onset of sprite production. The largest mass was reached for the 35-40 dBZ interval during periods of sprite generation at $1.7 \times 10^{7}$ and $1.2 \times 10^{7} \mathrm{~kg} \mathrm{~s}^{-1}$ corresponding to 2.7 and $11.5 \mathrm{~mm} \mathrm{~h}^{-1}$, respectively.

Most sprites were observed when the stratiform areas developed rapidly. Although the storms were of comparable size, the storm on 11 September produced lower convective precipitation mass values compared to the storm on 21 July as seen in reflectivity values larger than $40 \mathrm{dBZ}$. On the other hand, the sprite production rate was larger in the 21 July storm. This suggests that the production rate of sprites is related to the decay of the convective region which influences the electrical conditions inside the stratiform region, most likely through the rearward deposition of precipitation particles. This scenario is consistent with estimates of charge sources in the stratiform region with advection from convective parts amounting to $30 \%$ and local processes to $70 \%$ (e.g. Schuur and Rutledge, 2000). Local charging inside the stratiform region has been attributed mostly to the noninductive charging process of particles in the mesoscale updraft, rather than charging processes associated with melting (Schuur and Rutledge, 2000). The role played by the advection process is observationally supported by the downward sloping path of spider lightning along apparent snowfall trajectories (e.g. Carey et al., 2005, Ely et al., 2008). Advection and local stratiform charging may both be linked to the intensification of a front-to-rear mesoscale updraft. In our observations, the collapse of convective regions indicated by the decreasing - CG flash rates was followed by expanding stratiform precipitation and the occurrence of sprites. In both MCSs, sprites continued approximately 'till the moment that the 30-40 dBZ precipitation mass started to decrease. This suggests that the mesoscale updraft weakened and/or that the rearward advection of precipitation from the convective region decreased.

\subsection{Lightning activity and sprite production}

In both storms considered in this study, sprites were observed during a period beginning up to $2 \mathrm{~h}$ after the maximum rate of - CG flashes was reached and during an electric phase of the storm where the -CG flash rate was low and the relative proportion of +CG flashes was high. These characteristics are consistent with the findings of Lyons (1996) who reported that sprite production by an MCS was not correlated with the total CG flash activity and that most of the 36 sprites observed occurred at least $1 \mathrm{~h}$ after the maximum -CG flash rate was reached. In contrast, São Sabbas et al. (2003) found a good temporal correlation between -CG flash activity and sprite production in a very active storm over Kansas. This storm was so powerful that the number of $-C G$ flashes reached close to $100 \mathrm{~min}^{-1}$ compared to $14 \mathrm{~min}^{-1}$ in the European storms analyzed here (Figs. 6 and 11). We suggest that the system was so large that several separate regions were electrically active and that only those in the sprite-producing region should have been included in the analysis. Lyons et al. (2003) considered a storm case documented during the STEPS experiment, which produced 15 sprites. In this case the maximum sprite rate 

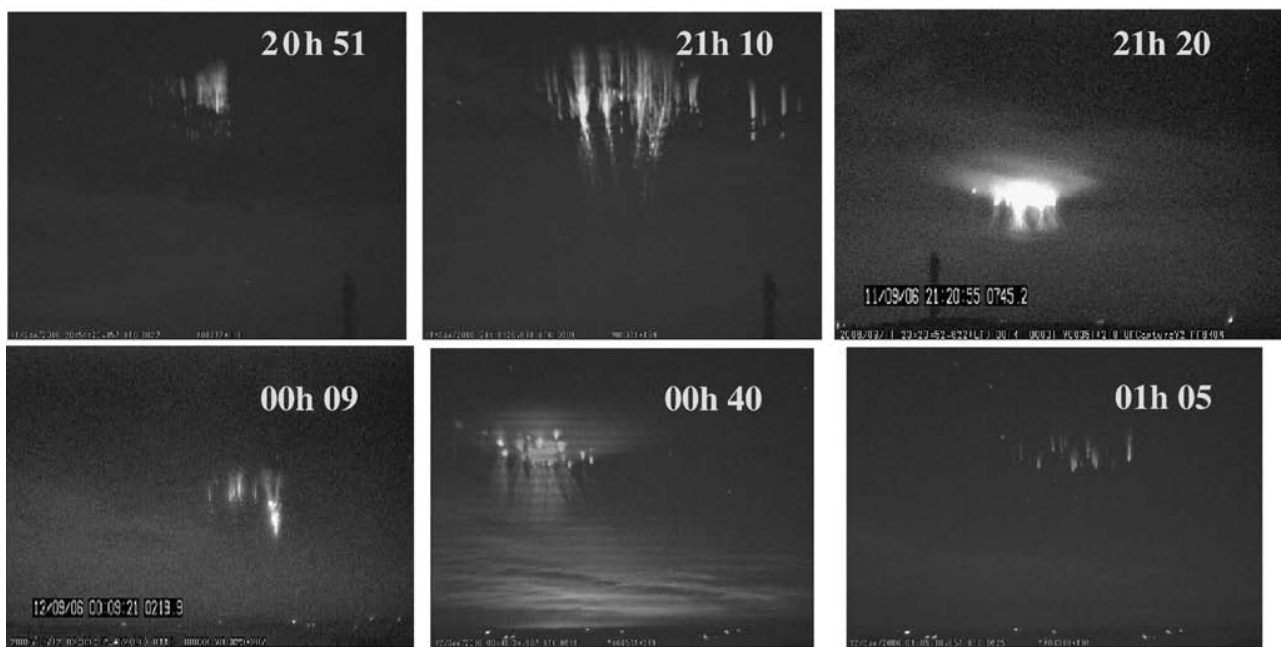

Fig. 8. Images of sprites observed from $S_{2}$ over the MCS on 11 September $\left(F O V=23^{\circ}\right)$.

was observed around 0600 UT with 6 events in less than $5 \mathrm{~min}$. They gave the CG flash numbers in 1-hour intervals and it was relatively low during the interval 0500-0600 UT. Another paper by Pinto et al. (2004) considered case studies of 6 sprite-producing storms observed in Brazil with a total of 16 sprites. Only one of these storms was an MCS and all storms appeared of moderate size and with moderate CG flash rates. During the periods of sprite production, they noted a high percentage of +CG flashes which generally corresponds to a low - CG flash rate and is also observed in our cases. Before the two MCSs produced sprites, the -CG flashes were strongly dominant as is observed in normal polarity thundercells.

Now we turn to the CG flash activity related to individual sprites. All sprites observed from the two storms were preceded by a detected +CG flash, except one which was produced 0-19 min after the first stroke $(-50.5 \mathrm{kA})$ of a threestroke - CG flash. The charge moment change of this negative

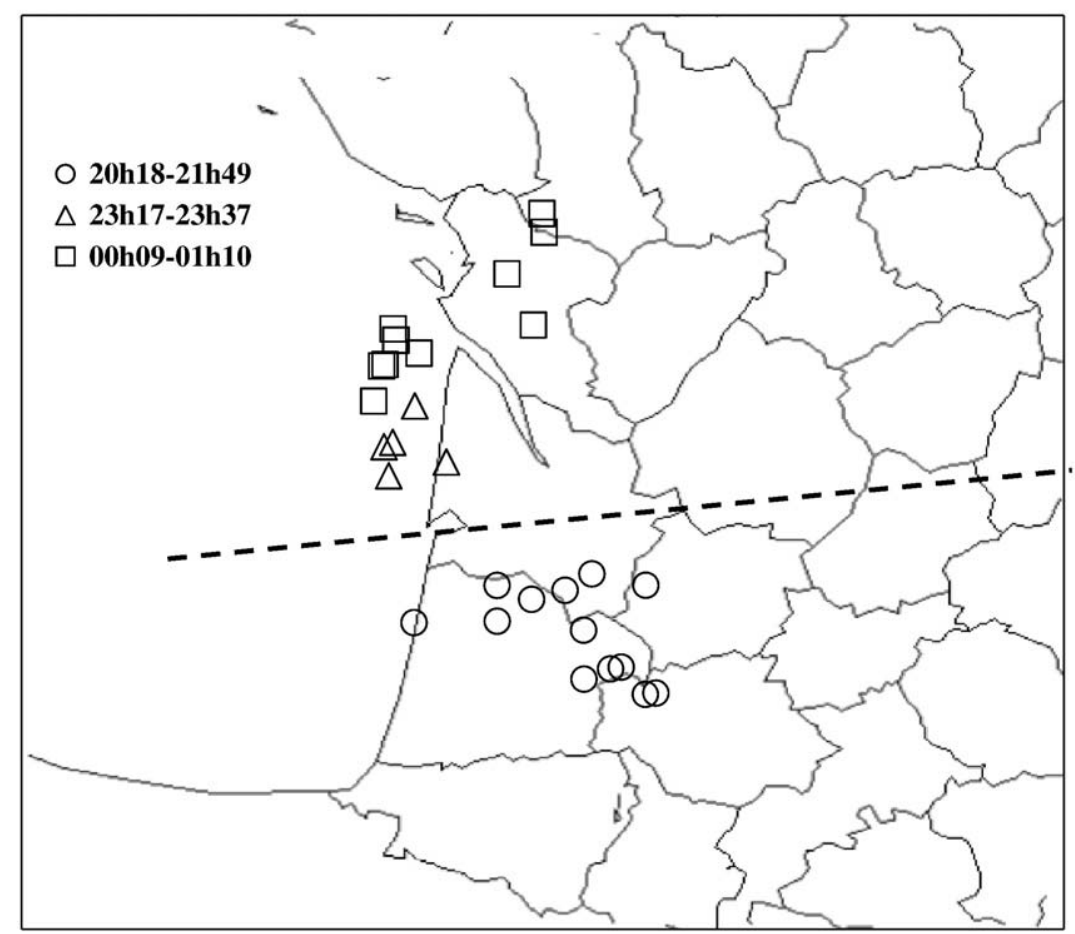

Fig. 9. Location of the SP+CG flashes on 11 September in the domain $\mathrm{F}_{2}$, for the three periods of production considered in the description of the system. The dotted line is used for separating two groups of CG lightning flashes. 

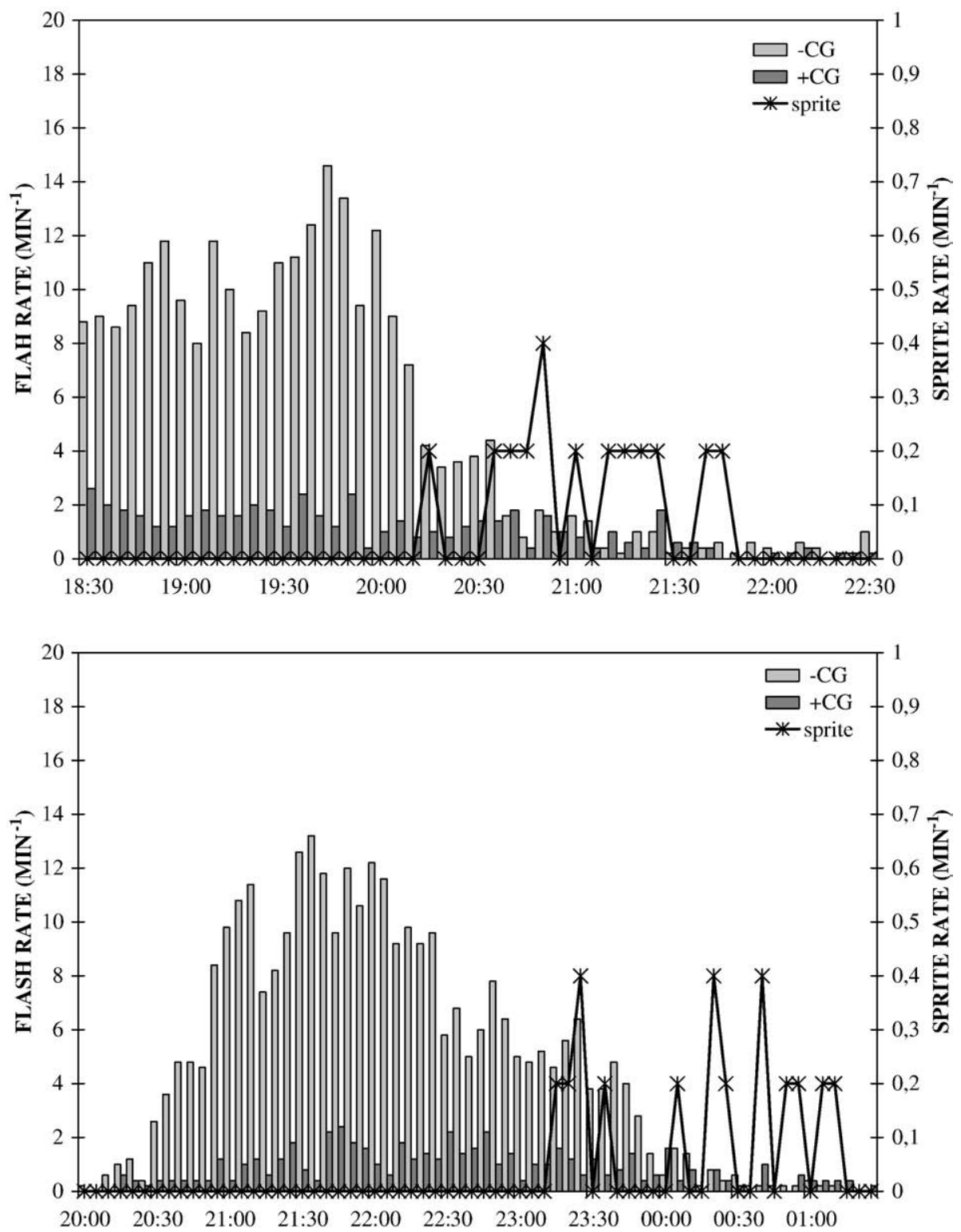

Fig. 10. Time series of the rates (5-minute averaged) for +CG and -CG lightning flashes, and sprites, produced by the MCS on 11 September, separating two periods of activity.

triggering stroke has been estimated from Extremely Low Frequency (ELF) electromagnetic wave observations from Mitzpe Ramon in Israel and the NCK station in Hungary to be about $-800 \mathrm{C} \mathrm{km}$.

In order to characterize the $53+\mathrm{CG}$ flashes involved in a sprite trigger, some parameters have been extracted from the data provided by the Météorage network. They are listed in Table 1. The +CG flashes are separated into two groups according to trigger $(\mathrm{SP}+\mathrm{CG})$ or no trigger $(+\mathrm{CG})$ of a sprite. Four parameters are considered: the peak current $(I)$, the multiplicity $(M)$, the time interval between a +CG flash and the following CG flash which can be positive or negative and which was produced in the same MCS (dt), and the number of CG flashes produced by the MCS within $1 \mathrm{~s}$ after a +CG flash
$(N)$. For each parameter, the average, maximum, minimum and median values are calculated. The CG flashes are determined based on data from Météorage which considers two successive strokes as different CG flashes when they are separated by at least $4 \mathrm{~km}$ in distance or/and by at least $0.5 \mathrm{~s}$ in time. The percentage in the last column of the table represents the proportion of +CG flashes which are followed by another CG flash within $1 \mathrm{~s}$.

First we note that the average value for the $\mathrm{SP}+\mathrm{CG}$ is around $60 \mathrm{kA}$ and about twice the average value of +CG flashes. This is very close to the value of $59.7 \mathrm{kA}$ found by Lyons et al. (2006) by considering a large number of cases and São Sabbas et al. (2003) estimating $60 \mathrm{kA}$ and with currents in the 40-50 kA range. The average value for the currents of +CG 


\section{July 2003: Integrated precipitation mass}

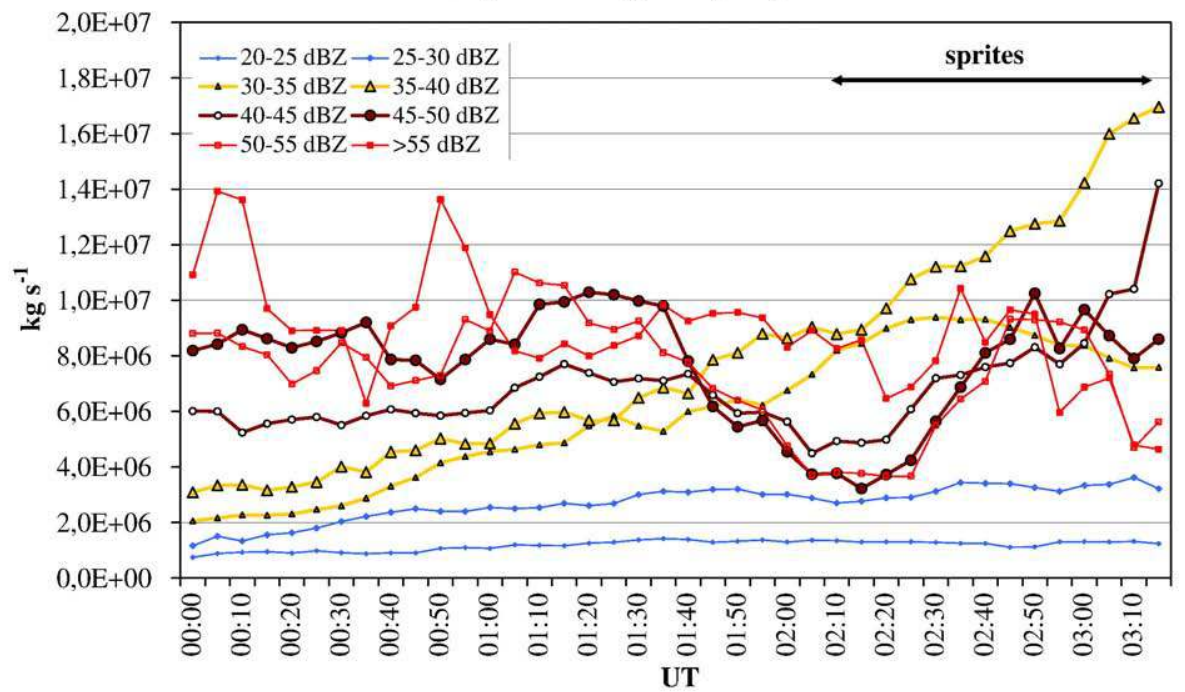

11-12 September 2006: Integrated precipitation mass

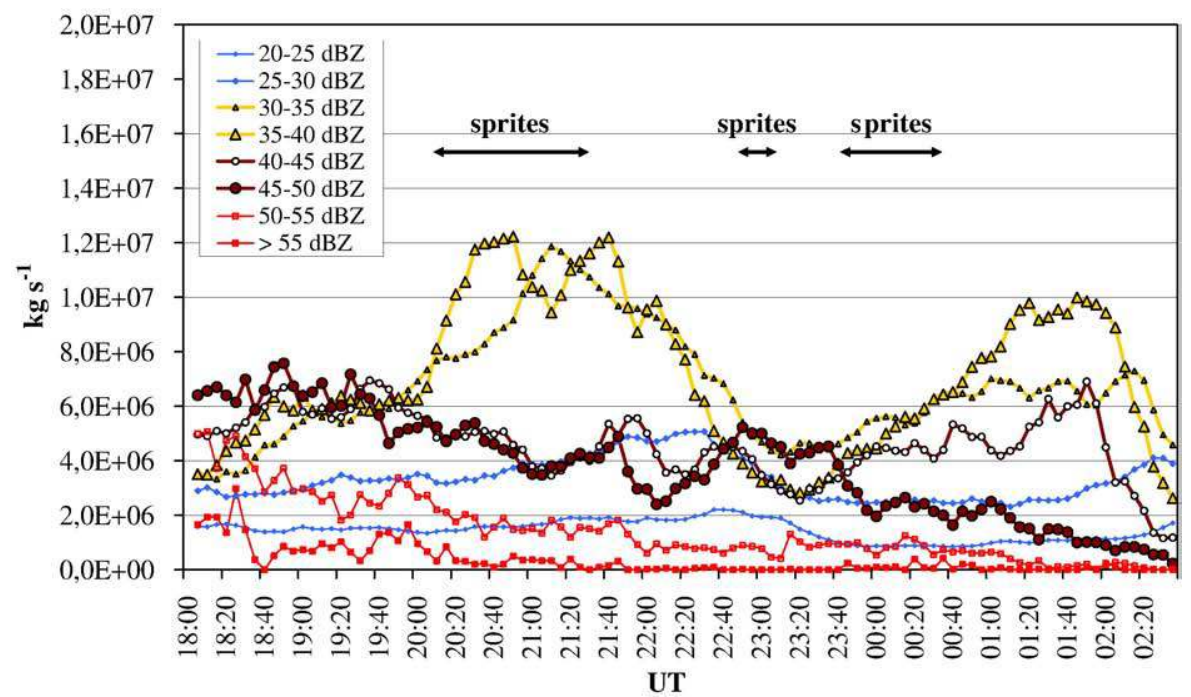

Fig. 11. Time series of the precipitation mass for different intervals of value of radar reflectivity in the thundercloud for 21 July (upper graph) and for 11 September (lower graph).

flashes without sprites was very close to $30 \mathrm{kA}$ for each of the three storm periods. Pinto et al. (2004) also found this ratio of 2 with a significant number of events. The values of the peak current for both types of +CG flashes were found within a large range. For each case, the ratio between the maximum and minimum values was larger than 10 . The minimum value for +CG flashes was $10 \mathrm{kA}$, the filtering value adopted for avoiding the misclassification of intracloud flashes (Cummins et al., 2006). Also in Lyons et al. (2003) and in Huang et al. (1999), the range of the peak current of the SP+CG flashes was large, with about one order of magnitude. It indicates the peak current is not a robust predictor for sprite triggering. The median values of the peak current were also much larger for SP+CG flashes, between 46.0 and $53.2 \mathrm{kA}$, compared to 18.825.2 kA for +CG flashes. For the multiplicity, no significant difference between SP+CG flashes and +CG flashes can be noted. In both groups of +CG flashes it remained low on average. However, the maximum value was always larger for the +CG flashes.

The time dt was always lower for the group of SP+CG flashes, for all storms considered and for most of its values, i.e. either average or maximum or median value. The minimum values were close to zero for both types of +CG flashes. The average values were clearly lower for the SP+CG flashes, for example $2.25 \mathrm{~s}$ compared to $5.13 \mathrm{~s}$ in the case of 21 July, and $1.64 \mathrm{~s}$ compared to $31.26 \mathrm{~s}$ in the case of the second period of 11 September. This difference is remarkable since the sprites were produced during periods with low CG flash rates and therefore with average time intervals between CG flashes larger than during the whole period of the storm. It indicates 
Table 1

Characteristics of the + CG lightning flashes produced by both MCSs, triggering a sprite $(\mathrm{SP}+\mathrm{CG})$, and not triggering a sprite $(+\mathrm{CG})$

\begin{tabular}{|c|c|c|c|c|c|c|c|c|c|}
\hline \multirow[t]{2}{*}{ Storm } & \multirow[t]{2}{*}{ Value } & \multicolumn{2}{|l|}{$I(\mathrm{kA})$} & \multicolumn{2}{|l|}{$M$} & \multicolumn{2}{|l|}{ dt (s) } & \multicolumn{2}{|l|}{$N$} \\
\hline & & $\mathrm{SP}+\mathrm{CG}$ & $+\mathrm{CG}$ & $\mathrm{SP}+\mathrm{CG}$ & $+\mathrm{CG}$ & $\mathrm{SP}+\mathrm{CG}$ & $+\mathrm{CG}$ & $\mathrm{SP}+\mathrm{CG}$ & $+\mathrm{CG}$ \\
\hline $21 / 07 / 2003$ & Average & 59.3 & 31.0 & 1.1 & 1.1 & 2.25 & 5.13 & 1.85 & 0.45 \\
\hline $27 \mathrm{SP}+\mathrm{CG}$ & Max & 185.8 & 175.3 & 2.0 & 5.0 & 15.99 & 47.89 & 5 & 5 \\
\hline \multirow[t]{3}{*}{$392+C G$} & Min & 17.5 & 10.0 & 1.0 & 1.0 & 0.01 & 0.00 & 0 & 0 \\
\hline & Median & 46.0 & 24.2 & & & 0.41 & 2.40 & & \\
\hline & & & & & & & & $85.2 \%$ & $30.2 \%$ \\
\hline $11 / 09 / 2006$ & Average & 58.9 & 31.3 & 1.2 & 1.2 & 8.73 & 9.31 & 1.92 & 0.71 \\
\hline Cell 1 & Max & 151.0 & 215.7 & 2 & 6 & 35.40 & 236.51 & 5 & 5 \\
\hline $12 \mathrm{SP}+\mathrm{CG}$ & Min & 8.0 & 10.0 & 1 & 1 & 0.00 & 0.00 & 0 & 0 \\
\hline \multirow[t]{2}{*}{$221+C G$} & Median & 53.2 & 18.8 & & & 0.28 & 1.49 & & \\
\hline & & & & & & & & $66.7 \%$ & $39.7 \%$ \\
\hline $11 / 09 / 2006$ & Average & 68.0 & 30.5 & 1.6 & 1.2 & 1.64 & 31.26 & 1.4 & 0.32 \\
\hline Cell 2 & Max & 178.0 & 127.7 & 3 & 5 & 10.69 & 424.34 & 3 & 5 \\
\hline $14 \mathrm{SP}+\mathrm{CG}$ & Min & 14.8 & 10.0 & 1 & 1 & 0.07 & 0.00 & 0 & 0 \\
\hline \multirow[t]{2}{*}{$206+C G$} & Median & 48.9 & 25.2 & & & 0.35 & 5.49 & & \\
\hline & & & & & & & & $85.7 \%$ & $26.5 \%$ \\
\hline
\end{tabular}

I, $M, \mathrm{dt}$, and $N$ are the peak current of the +CG flash, the multiplicity of the +CG flash, the time interval between a + CG flash and the following CG flash (+ or -), and the number of CG flash (+ and -) within $1 \mathrm{~s}$ after a +CG flash, respectively. The percentage in the last column is the proportion of $+\mathrm{CG}$ flashes which are followed by at least 1 CG flash within $1 \mathrm{~s}$.

the $\mathrm{SP}+\mathrm{CG}$ flashes could have a specific feature. For the median value of this time $\mathrm{dt}$, the difference between both groups of +CG flashes appears still larger. As a matter of fact, it was always lower than $0.5 \mathrm{~s}$ : $0.41,0.28$, and $0.35 \mathrm{~s}$, for the three periods in Table 1, respectively. It means dt was often very low since the median value shares the group into two halves. Such low values indicate the following CG flash could be associated with the SP+CG flash in the same lightning process in many cases. However, the detection system counted them as new CG flashes because the distance was too large to be considered as a stroke of the same CG flash. So, these following CG flashes could be remote strokes involved in the same lightning process with long-distance propagation.
Observations of multi-stroke +CG flash parents were reported by Lyons (1996) for several cases of sprite but we can wonder if the criteria for associating strokes in a same CG flash were different for the study by Lyons. Fig. 12 displays a distribution of the distance between the striking points of the SP+CG flash and of the following CG flash versus $\mathrm{dt}$ for the three storm periods and for the cases with dt lower than $0.5 \mathrm{~s}$ (31 cases over the $53 \mathrm{SP}+\mathrm{CG}$ flashes). Dt exceeded $1 \mathrm{~s}$ for $10 \mathrm{SP}+\mathrm{CG}$ flashes. The distance tends to increase with dt, which suggests a propagation of a lightning process between both CG flashes involved. A linear curve fitting provides a coefficient of about $10^{5} \mathrm{~m} \mathrm{~s}^{-1}$ for the ratio between distance and time. This value corresponds with the velocity of the negative leader propa-

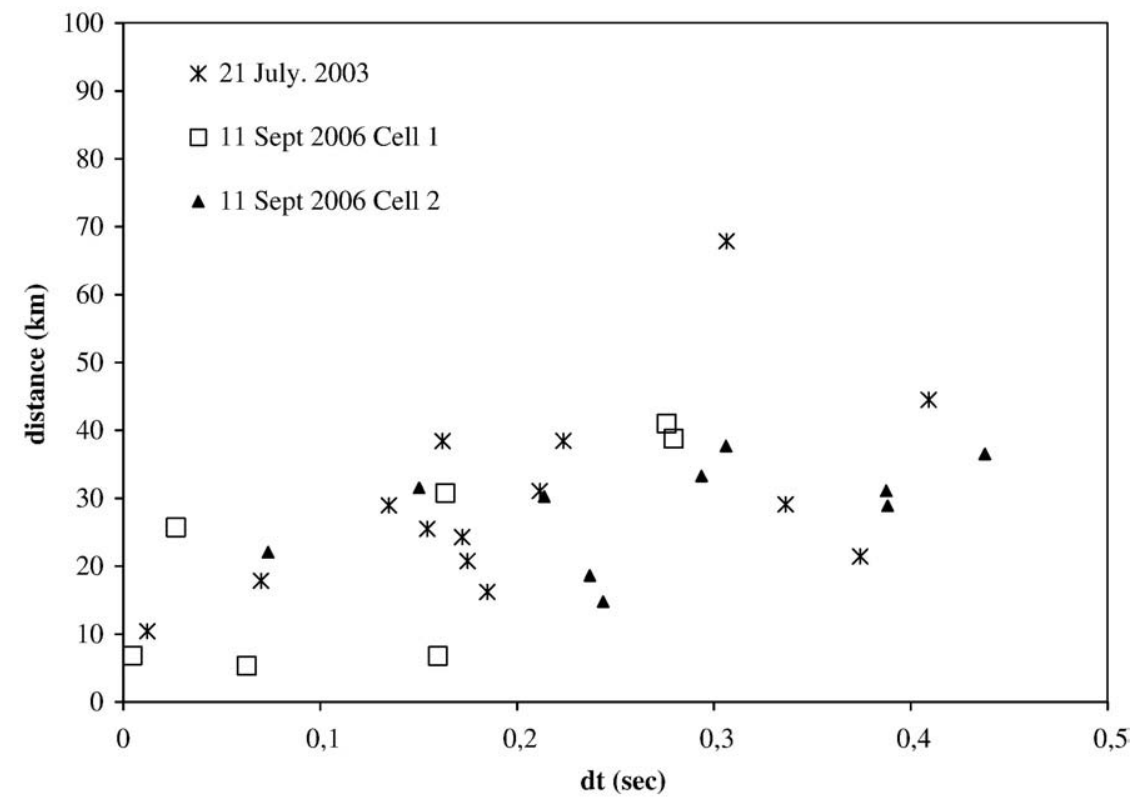

Fig. 12. Diagram of the distance versus time interval $\mathrm{dt}$ between an $\mathrm{SP}+\mathrm{CG}$ flash and the following $\mathrm{CG}$ flash for the cases with dt lower than $0.5 \mathrm{~s}$. The three periods are considered in the graph. 
gating toward or within a positive charge region (Mazur et al., 1998). In support of this view, other authors observed sprites to be associated with lightning discharges horizontally propagating over long distances, Stanley (2000) in Florida and Lyons et al. (2003) during STEPS.

The number $N$ of CG flashes following a +CG flash within $1 \mathrm{~s}$ (last column of Table 1) supports this assumption. So, for the SP+CG flashes $N$ was 2-4 times larger than for the other $+C G$ flashes. Even if the SP+CG flashes occurred during periods with low CG flash rates, $N$ for this type of flash was always larger than 1 on average. The proportion of the SP+CG flashes with at least $1 \mathrm{CG}$ flash produced within $1 \mathrm{~s}$ was $66.7 \%$, $85.2 \%$, and $85.7 \%$, for the three storm periods, respectively. It was always lower than $40 \%$ for the other +CG flashes. Fig. 13 displays the evolution of the cumulative CG flash number for the first sprite production period of the 11 September MCS, between 2000 and 2200 UT. The time is expressed in hours and zero corresponds to 2000 UT. The 12 sprites produced after an SP+CG flash are indicated with circles superimposed on the curve. Multiple CG flashes are well visible under the form of small jumps of the CG flash number and several sprites were produced simultaneously to such jumps. However, not all jumps corresponded with a sprite as for example at 1.135 and $1.425 \mathrm{~h}$. At $1.135 \mathrm{~h}$, the detection system counted 6 different CG flashes within 0.5 s, all -CG flashes and some of them with several strokes. Furthermore, the distance between two consecutive CG flash striking points was lower than $10 \mathrm{~km}$, except for the two last ones with $40 \mathrm{~km}$. For the lightning process at $1.425 \mathrm{~h}$, the number of CG flashes was 5 , including $4+C G$ and $1-C G$, and the distance between the striking points of two consecutive CG flashes was lower than $30 \mathrm{~km}$. For comparison, at $1.449 \mathrm{~h}$, a lightning sequence associated with a sprite involved 7 CG flashes, 5 +CG with a peak current close to $130 \mathrm{kA}$ for two of them, and $2-\mathrm{CG}$. The distances between the striking points of these 7 CG flashes ranged up to $40 \mathrm{~km}$. The presence of several CG flashes during the lightning process associated with the sprite can indicate a long-propagating lightning but we cannot conclude that this feature is necessary for sprite triggering. In some cases of sprites without the presence of multiple CG flashes, VHF detection should be necessary to check this kind of propagation which can be assigned to the negative leader moving towards positive charge within the cloud.

\section{Conclusion}

Two MCSs in France each with 27 recorded sprite events have been analyzed in terms of cloud structure, precipitation, and lightning activity. The main characteristics of these storms are described with data from the French radar network operated by the French weather service MétéoFrance and from the French CG flash detection network managed by the company Météorage. Both MCSs were of similar size $\left(120,000 \mathrm{~km}^{2}\right)$, and they produced sprites during distinct periods, one for the storm of 21 July and two for that of 11 September. The sprites were produced when the stratiform area was clearly developed and when the amount of precipitation produced by regions with reflectivity values between 30 and $40 \mathrm{dBZ}$, was increasing and becoming dominant. A significant decrease of the -CG flash rate preceded the sprite periods, while the +CG flash rate remained constant. So, +CG flashes constituted around 50\% of all CG flashes during the sprite periods. All sprites detected were associated with an SP+CG flash, except one which was observed after a -CG flash as detected by the Météorage network. The charge moment change of this -CG flash was estimated at $-800 \mathrm{C} \mathrm{km}$, according to ELF radiation detections. The SP+CG flashes had peak currents about two times larger on average than the other +CG flashes, around $60 \mathrm{kA}$ for each period of sprite production. This average is very close to

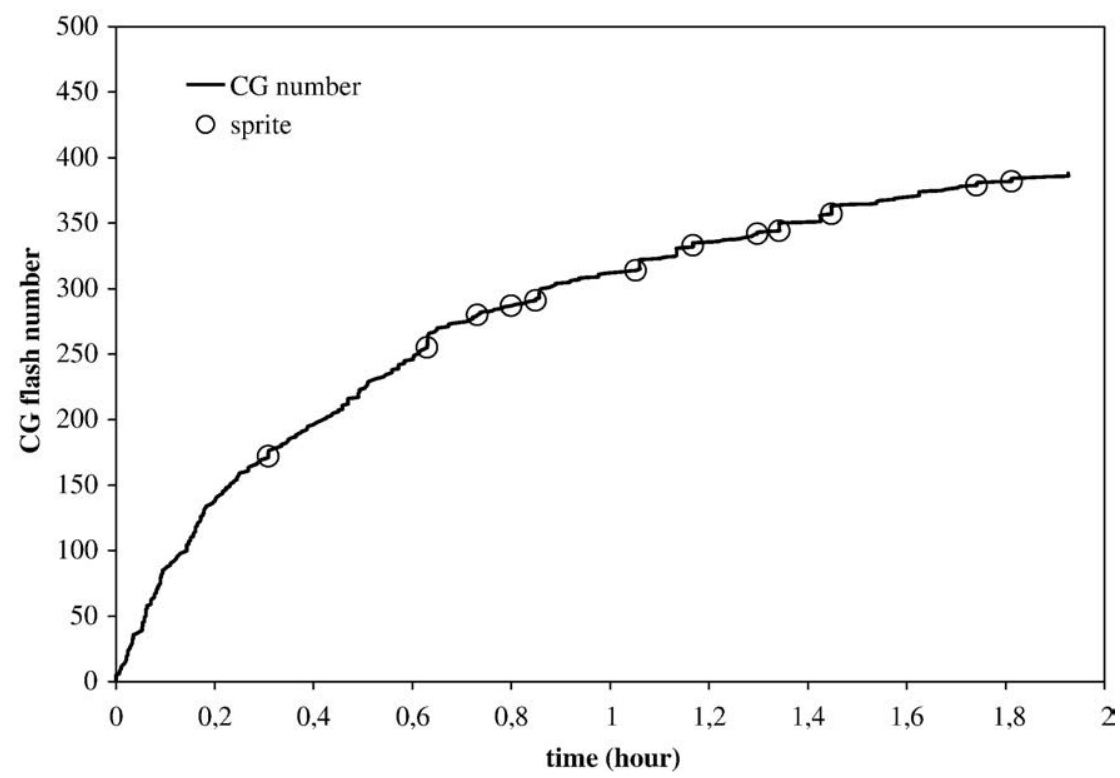

Fig. 13. Evolution of the cumulative CG flash number during the first period of sprite production (2000-2200 UT) for the MCS on 11 September, 2006. The circles indicate the occurrence of the 12 sprites. 
several values found in previous studies (Lyons et al., 2006; São Sabbas et al., 2003) but the range of the currents was very large for each period, roughly of one order of magnitude.

The CG lightning activity following the SP+CG flashes has been analyzed and compared with that following other $+\mathrm{CG}$ flashes not linked with sprites. It appears the SP+CG flashes were characterized by a shorter average time interval with the following CG flash. The median value of this time interval was less than $0.5 \mathrm{~s}$ for the three active periods studied from the two MCSs, which means the SP+CG flash could often be part of a multi-CG flash lightning process.

\section{Acknowledgements}

This study was partly supported by the Research Training Network 'Coupling of Atmospheric Layers' (CAL), sponsored by the EU FP5 program under contract $n^{\circ}$ HPRN-CT-200200216. The authors would like to thank Météorage, for providing the data on the CG lightning flashes and MétéoFrance, the French weather service, for providing the data from the radar network. The authors thank Joszef Bor from the Geodetic and Geophysical Research Institute in Hungary, and Eran Greenberg from Tel-Aviv University, for providing a charge moment change value.

\section{References}

Barrington-Leigh, C.P., Inan, U.S., Stanley, M., Cummer, S.A., 1999. Sprites triggered by negative lightning discharges. Geophys. Res. Lett. 26 (24), 3605-3608.

Boccippio, D.J., Williams, E.R., Heckman, S.J., Lyons, W.A., Baker, I.T., Boldi, R. 1995. Sprites, ELF transients, and positive ground strokes. Science 269, 1088.

Carey, L.D., Murphy, M.J., McCormick, T.L., Demetriades, N.W.S., 2005 Lightning location relative to storm structure in a leading-line, trailingstratiform mesoscale convective system. J. Geophys. Res. 110, D03105. doi:10.1029/2003JD004371.

Cummer, S.A., Lyons, W.A., 2005. Implications of lightning charge moment changes for sprite initiation. J. Geophys. Res. 110, A04304. doi:10.1029/ 2004JA010812.

Cummins, K.L., Murphy, M.J., Bardo, E.A., Hiscox, W.L., Pyle, R.B., Pifer, A.E., 1998. NLDN'95, a combined TOA/MDF technology upgrade of the US National Lightning Detection Network. J. Geophys. Res. 103, 9,035-9,044.

Cummins, K.L., Cramer, J.A., Biagi, C., Krider, E.P., Jerauld, J., Uman, M.A., Rakov, V.A., 2006. The U.S. National Lightning Detection Network: post-upgrade status, paper presented at 2nd Conf. on Meteorological Applications of Lightning Data, Amer. Meteorol. Soc., Atlanta. paper 6.1.

Ely, B.L., Orville, R.E., Carey, L.D., Hodapp, C.L., 2008. Evolution of the total lightning structure in a leading-line, trailing-stratiform mesoscale convective system over Houston, Texas. J. Geophys. Res. 113, D08114. doi:10.1029/2007JD008445.

Farges, T., Blanc, E., Le Pichon, A., Neubert, T., Allin, T.H., 2005. Identification of infrasound produced by sprites during the Sprite2003 campaign. Geophys. Res. Lett. 32, L01813. doi:10.1029/2004GL021212.

Franz, R.C., Nemzek, R.J., Winckler, J.R., 1990. Television image of a large upward electrical discharge above a thunderstorm system. Science 249 , 48-51.
Hayakawa, M., Nakamura, T., Hobara, Y., Williams, E., 2004. Observation of sprites over the Sea of Japan and conditions for lightning-induced sprites in winter. J. Geophys. Res. 109, A01312. doi:10.1029/2003JA009905.

Hu, W., Cummer, S.A., Lyons, W.A., Nelson, T.E., 2002. Lightning charge moment changes for the initiation of sprites. Geophys. Res. Lett. 29 (8), 1279. doi:10.1029/2001GL014593.

Huang, E., Williams, E., Boldi, R., Heckman, S., Lyons, W., Taylor, M., Nelson, T., Wong, C., 1999. Criteria for sprites and elves based on Schumann resonance observations. J. Geophys. Res. 104 (D14), 16,943-16,964.

Lyons, W.A., 1994. Characteristics of luminous structures in the stratosphere above thunderstorms as imaged by low-light video. Geophys. Res. Lett. 21 (10), 875-878.

Lyons, W.A., 1996. Sprite observations above the U.S. High Plains in relation to their parent thunderstorm systems. J. Geophys. Res. 101 (D23), 29641-29652. doi:10.1029/96JD01866.

Lyons, W.A., Armstrong, R.A., Bering III, E.A., Williams, E.R., 2000. The hundred year hunt for the sprite, Eos Trans. AGU 81 (33), 373.

Lyons, W.A., Nelson, T.E., Williams, E.R., Cummer, S.A., Stanley, M.A., 2003. Characteristics of sprite-producing positive cloud-to-ground lightning during the 19 July 2000 STEPS mesoscale convective systems. Mon. Weather Rev. 131, 2417-2427.

Lyons, W.A., Andersen, L.M., Nelson, T.E., Huffines, G.R., 2006. Characteristics of sprite-producing electrical storms in the STEPS 2000 domain. On line summary and CD, 2nd Conf. on Meteorological Applications of Lightning Data. AMS, Atlanta. 19 pp.

Maddox, R.A., 1980. Mesoscale convective complexes. Bull. Am. Meteorol. Soc. 61, 1374-1387. doi:10.1175/1520-0477.

Marshall, J.S., Palmer, W.M., 1948. The distribution of raindrops with size. J. Meteorol. 5, 165-166.

Mazur, V., Shao, X., Krehbiel, P.R., 1998. “Spider" lightning in intracloud and positive cloud-to-ground flashes. J. Geophys. Res. 103 (D16), 19,811-19,822.

Neubert, T., Allin, T.H., Stenbaek-Nielsen, H., Blanc, E., 2001. Sprites Over Europe. Geophys. Res. Lett. 28 (18), 3585-3588.

Neubert, T., Allin, T.H., Blanc, E., Farges, T., Haldoupis, C., Mika, A., Soula, S., Knutsson, L., van der Velde, O., Marshall, R.A., Inan, U.S., Sátori, G., Bór, J., Hughes, A., Collier, A., Laursen, S., Rasmussen, I.L., 2005. Co-ordinated observations of transient luminous events during the EuroSprite2003 campaign. J. Atmos. Sol.-Terr. Phys. 67, 807-820.

Pasko, V.P., Stanley, M.A., Mathews, J.D., Inan, U.S., Wood, T.G., 2002. Electrical discharge from a thundercloud top to the lower ionosphere. Nature 416, 152-154. doi:10.1038/416152a.

Pinto Jr., O., Saba, M.M.F., Pinto, I.R.C.A., Tavares, F.S.S., Naccarato, K.P., Solorzano, N.N., Taylor, M.J., Pautet, P.D., Holzworth, R.H., 2004. Thunderstorm and lightning characteristics associated with sprites in Brazil. Geophys. Res. Lett. 31, L13103. doi:10.1029/2004GL020264.

São Sabbas, F.T., Sentman, D.D., 2003. Dynamical relationship of infrared cloudtop temperatures with occurrence rates of cloud-to-ground lightning and sprites. Geophys. Res. Lett. 30 (5), 1236. doi:10.1029/2002GL015382.

São Sabbas, F.T., Sentman, D.D., Wescott, E.M., Pinto Jr., O., Mendes Jr., O., Taylor, M.J., 2003. Statistical analysis of space-time relationships between sprites and lightning. J. Atmos. Sol.-Terr. Phys. 65 (5), 525-535.

Schuur, T.J., Rutledge, S.A., 2000. Electrification of stratiform regions in mesoscale convective systems. Part II: two-dimensional numerical model simulations of a symmetric MCS. J. Atmos. Sci. 57, 1983-2006.

Stanley, M.A., 2000. Sprites and their parent discharges, Ph.D. dissertation, 163 pp., N. M. Inst. of Mining and Technol., Socorro, N. M.

Williams, E., Downes, E., Boldi, R., Lyons, W., Heckman, S., 2007. Polarity asymmetry of sprite-producing lightning: a paradox? Radio Sci. 42, RS2S17. doi:10.1029/2006RS003488.

Wilson, C.T.R., 1925. The electric field of a thunderstorm and some of its effects. Proc. Royal Soc. London 37, 32D.

Yair, Y., Israelevich, P., Devir, A.D., Moalem, M., Price, C., Joseph, J.H., Levin, Z., Ziv, B., Sternlieb, A., Teller, A., 2004. New observations of sprites from the space shuttle. J. Geophys. Res. 109, D15201. doi:10.1029/2003JD004497. 